\title{
DIALECTICAL LOGIC OF CULTURAL AND ACTIVITY PSYCHOLOGY AS A TOOL TO IDENTIFY THE NATURE OF MENTAL REALITY
}

\begin{abstract}
Elena E. Sokolova
Lomonosov Moscow State University Moscow

This essay is aimed at considering the possibility itself of "metacomprehension" of the mental reality so cherished by Lev Vygotsky from the positions of cultural and activity psychology. It is demonstrated that the program Vygostky outlined for creating the new "general psychology" involves the use of dialectical logic (as opposed to the contemporary projects of "integrative psychology" based on the "and - and" logic). Applied in a creative way to the problem of nature of mental reality, the dialectical logic let the adherents of Alexei Leontiev school draw the conclusion that activity can be regarded as a substance of mind and that, consequently, the mind can be regarded as a "functional organ" of activity. Such an interpretation of the mental reality makes it possible to resolve a number of theoretical and practical psychological problems anew.
\end{abstract}

Keywords: L.S. Vygotsky, A.N. Leontiev school, dialectical logic, general psychology, activity, mind, functional organ.

The most fundamental issues of psychology related to professional self-identification of psychologists have been discussed at various psychological congresses and conferences as well as on the pages of scientific periodicals recently. Thus, the psychological revue issued by the Russian Higher School of Economics offered for discussion the following two related issues: whether it is generally possible to "metacomprehend" the mental reality, as it was cherished by Lev Vygotsky; and what is the nature of reality studied by psychology (Editorial, 2010, p. 74). I'd like to give my own reply to the first question: I believe that the Vygotsky metacomprehension of the mental reality is practicable if we accept his methodological basis for such metacomprehension involving indispensably a certain reflection prior to resolving this or that issue of 
psychological science. As Vygotsky put it in his Historical sense of psychological crisis, "No science provides for such a variety and plenitude of methodological problems, for such tightly tied knots and insoluble contradictions as our science does. That is why no step here should be taken without a thousand prior calculations and precautions" (Vygotsky, 1982, p. 418). As far as the second question is concerned, I will provide my answer later, once the essence of the reply to the first one is clarified.

\section{General Psychology as Dialectics of Psychology (L.S. Vygotsky)}

It is known that in his methodological work referred above Lev Vygotsky sequentially advanced the idea that the scientific psychology should be totally restructured to create a general science, general psychology that is going to be the "dialectics of psychology" (ref. L. Vygotsky, 1982, pp. 419, 420). During the past few decades the word "dialectics" became in Russia a kind of dirty word, which is easy to understand if we consider that many of methodologists link it (without being wrong) to the detested Marxism. But it should be pointed out that Lev Vygotsky treated the task of creating a Marxist psychology as a historical task of psychological science. To him, the notion of Marxist psychology is identical to the notion of scientific psychology in general (Ibid., p. 435). To Lev Vygotsky, "the Marxist psychology includes every genuine scientific trait of psychology; the notion of Marxist psychology is wider than a school or a trend (Ibid.). Vygotsky repudiated the quotational use of Marxism but he insisted that the Karl Marx's method should be used in psychology and that is why he constantly repeated in his polemical work that "psychology needs its own Capital to be written" (Ibid., p. 420). I would not comment here on allegations stating that Lev Vygotsky didn't have the choice and just had to write this way due to the certain historic conditions. Those statements are nothing but naïve.

This was not, however, Karl Marx who had invented the dialectical method he applied while writing his Capital. This method appeared as result of development of dialectical thought since the Ancient Greek times. During the Modern Age this dialectical method was further de- 
veloped by Benedictus de Spinoza ${ }^{1}$, favorite author of Lev Vygostky, and, of course, by Georg Hegel whose dialectical system is so complicated that it takes much effort even to understand it, not to mention mastering it. Thus, for example, Victor Allakhverdov, who I deeply respect, wrote in one of his recent works on the actual crisis in psychology and possible ways out of it: "The time has really come to put a stopper to the phrase-mongering practiced by Hegel and announcing the existence of a very special dialectical logic with contradiction being a norm thereof." (Allakhverdov, 2009, p. 83).

The limited framework of this article does not allow me to make a prolonged digression to the field of dialectical logic mastered by both Lev Vygotsky and Alexei Leontiev. However, I feel that I should say a few words on it since as far as it can be seen from the contemporary works modern authors who write on methods in psychology misunderstand it to some extent. In addition to that, dialectics is closely connected with monistic understanding of reality (Naumenko, 1968), and in Russia has also become a kind of dirty word. So, it is worth considering the modern methodological discussions arisen in literature to once more clarify the methodological principles that were taken by L. Vygotsky as a basis of his psychology and by A. Leontiev as a basis for his theory of activity that I am going to talk about in the second part of this work.

First of all, it is necessary to define the terms. Philosophers understand the word monism as "considering the diverse phenomena of the universe in the light of oneness, of single fundamental" (Philosophy, 2004, p. 523), and pluralism means accepting lots of such fundamentals. Thus, we consider the ontological monism, i.e. accepting ontological oneness of the universe notwithstanding the diversity of its manifestations. So Spinoza, being a monist, treated the universe as a single and continuous substance manifested in the diversity of its various modi. This monistic approach applied by Spinoza is opposed to the Cartesian dualism that was further taken as a basis for many of the paradigms.

The modern critics of monism understand it primarily as gnosiological (categorial) monism. So they often reproach monists for reduc-

\footnotetext{
1 Vygotsky wrote that the name of Benedictus de Spinoza "shines like a guiding star for the researches to come" (Vygotsky, 1984, p. 297). And recently published Vygotsky's diaries contain even a more poetic saying: "The great Spinoza's works give us the light throughout centuries like distant stars. This is only the psychology of future that can put the ideas of Spinoza to practice." (Vygotsky, 2006, p. 295).
} 
ing the whole diversity of mind descriptions to one single category (e.g. to the category of activity) and which makes their understanding of the mental reality one-sided. Versatility is thus opposed to such "one-sided" view to the reality under study. A. Yurevich believes that this approach flows directly from the "diversity of mind itself" that, in his opinion, may be interpreted either as activity, or as behavior, or as image transformation, or in any other way; and this diversity "as itself serves quite a trivial argument for unavoidability of different approaches to study it" (Yurevich, 2005, p. 124). In Yurevich's opinion, it is principally impossible to create a single metatheory and that is why "the monist way to unify psychology <...> loses its adherents" (Yurevich, 2007, p. 506). Yurevich deems the "methodological liberalism" and "methodological pluralism" to be the most appropriate approaches to resolving the historic task of creating an "integrative psychology". The author believes that the latter approach is "not just the validation of disintegration in psychology being methodologically inevitable, but also a way to get it integrated, in a manner similar to relations prevailing in the feudal society" (Ibid.).

According to M. Guseltseva, the "one-sidedness" of monist approach is due to the fact that the monists acting in a self-centered way oppose their position to all the other viewpoints not going beyond the logic of dilemma way of thinking, in other words, the "or - or" logic. In her opinion, the new "pluralistic" approach to the problems resolved by the psychologists should be based on antinomy way of thinking logic, or the "and - and" logic. "Antinomy way of thinking, she writes, is proved to be more heuristic than the dilemma way of thinking. Antinomy way of thinking means that one is capable of accepting different propositions the thesis and the antithesis - as parts of an ensemble." (Geseltseva, 2007, p. 105).

However, in our opinion, the "and - and" logic results in summative addition of different viewpoints and approaches which does not form a comprehensive picture of the reality studied by psychology. The metaphors of mosaic, collage, and kaleidoscope etc are typically used for describing such a "pluralistic" psychology. Another - dialectical - logic being the base of monism in the non-vulgar sense of word is needed to truly comprehend the integrity of the reality studied by psychology. This type of logic is neither reducible to the "or - or" logic (the dogmatist logic of thinking, as Hegel used to put it), nor to the "and - and" logic 
(the skeptic logic of thinking). Dialectical logic is not a phrase-mongering that accepts contradictions, but it is the way to resolve an identified contradiction basing on the further in-depth study of the subject.

In 1958 the master of dialectics E. Ilyenkov said in the report at the Institute of Philosophy of the USSR Academy of Sciences that the opponents of the Hegelian dialectics "simply prefer to find faults with Hegel" not quite understanding his ideas (Ilyenkov, 1999, p. 253). And that is why, in Ilyenkov's words, they do not progress from Hegel on but they go back to Kant, since "that was Kant to whom contradiction meant the same thing as non-sense $\langle\ldots\rangle$. That was Kant who knew and accepted only one way to resolve contradictions; that is the way 'to separate the opposite theses into two different relations."' (Ibid.). However, Hegel (and further Marx) understands and, consequently, resolves contradictions in a different manner. Once a contradiction is discovered in the perceived reality "at the same time and relating to the same things", a researcher keeps his specific studies of the subject and sooner or later will find the way that "the subject itself in the course of its evolution solves and affects this contradiction." (Ilyenkov, 1999, p. 254). This is exactly the way how Marx resolved the following contradiction: why does a surplus value arise under the law of value if this contradicts the law of value? To resolve this contradiction the commodity-money domain was put to the further analysis and a commodity for which consummation is identical to production of new value, i.e. the man power was found.

This is why L. Vygotsky reiterated that psychology needs its own Capital to be written; in other words, he wanted this kind of dialectical logic to be applied to resolving psychological problems. This type of logic might help us to resolve the "supertask" of the psychological science, i.e. to create the "particular psychology of man" (according to Hegel, "particular" means the "unity of the diverse"). However, the "and - and" logic (or the "not only ... but also" logic) proposed today by pluralists means just adding (simple summation) different "abstract" knowledge about the studied subject and eventually discarding the possibility to view psychology as an integrated science.

During the recent years the Russian psychological literature has spread the opinion that psychology is a science of many subject-matters and that "every theory in psychology constitutes its own subject-matter and method of studying." (Kornilova \& Smirnov, 2006, p. 152), or that psychology is a conglomeration of various disciplines and that is why the 
word "psychologist" is the only thing that unites psychologists working at different fields (ref. V. Petrenko, 2005, p. 292). Thus, the best way to describe psychology is to imagine a sky-scrapper where each floor has its own standards for organizing knowledge (Krichevets, 2005). And in general, all the psychological theories should be regarded as "different interpretations of mental reality" (Yurevich, 2003, p. 351), so the definitions "more correct" or "less correct" cannot be applicable to all these theories.

Does that mean that psychology must be deprived of its status of science at all? V. Allakhverdov pointed out the possibility of the danger when he was talking about the above subject. And I completely share his opinion. V. Allakhverdov often asks the following question addressing to the adherents of "interpretations equivalency": "So, if we do not know the absolute truth, than why isn't it possible to choose the best position? Science always involves choice. Today we know that both the Ptolemy's and Copernicus's theories were wrong, however, the right choice was made in favor of the latter [which was of brilliant nonsense] $<\ldots$. . The Lavoisier's theory which was far from perfection came to change the phlogiston theory as well. It is really hard to imagine the state of contemporary physics and chemistry if the choices were not made" (Allakhverdov, 2009, p. 51).

V. Allakhverdov is preoccupied by the today state of affairs in psychology but he is sure that the situation is going to change soon since psychology has matured and it has only to wait till "its Newton" comes and makes all the necessary summarizing (ref. V. Allakhverdov, 2010, p. 88). I absolutely share the opinion that psychologists must follow a "common way" and, to my mind, it means creating a particular psychology as L. Vygotsky defined it; however, it seems to me, that a "Newton of psychology" will not be able to resolve the task. In 1920s L. Vygotsky wrote in this regard: "Our task is not to mark out our job against the general flow of the psychological work of the past, but to find a certain new basis and to make our work the integral part of the whole psychological science. This is not our school that we would like to mark out, but we would like to draw the line between science against non-science, psychology against non-psychology. The psychology we are talking about does not still exist. It is to be created and not by a single school. Many generations of psychologists are going to work on it. As W. James used to put it, psychology will have its genii and its common researchers; and their joint 
work for generations will form psychology in the proper meaning of the word" (Vygotsky, 1982, p. 436).

It should be noted that L. Vygotsky being a definite ontological monist did not, however, act in a self-centered way opposing his position to all the others. L. Vygotsky was going to create a new scientific system of psychology not by eclectically unifying different viewpoints, but by revising them fundamentally considering the requirements of practice. This is why he deemed it necessary to put all the psychological concepts that ever existed to a critical analysis in terms of their scientific contents. Thus, one cannot write a serious methodological work on psychology without having a detailed knowledge of its history or a comprehension of the logic of its overall development.

It seems that the lack of knowledge on history of our discipline and the scientific environment it developed in prevents some methodologists from appreciating many existing solutions of the psychological problems that are based on the dialectical logic. Vygotsky's idea to "create the particular psychology of man" was put to practice by the members of A. Leontiev school who created the psychological theory of activity. And it seems like the situation around this theory is very much similar to that around the Hegel's system as E. Ilyenkov put it: without understanding it they prefer to find faults with it or discard it as unnecessary "in the new historical conditions." But in any case, its fundamental principals are not put to any critical analysis. However, it should be mentioned that this theory is purposefully based on the dialectical logic and not on the skeptic logic or the dogmatist logic Hegel insisted on overcoming.

\section{Dialectical Solution to the Problem of Nature of the Mental Reality Offered by the Members of A. Leontiev School}

However incredible it may seem, but the psychology of activity is misinterpreted even on the pages of the Editorial of Psychology revue that opened the discussion mentioned at the very beginning of this article. The Editorial provides for a list of seven "possible answers" to the question of the nature of mental reality. To spare the time and place, I am not going to cite the complete list here. However, it should be noted that the way the members of A. Leontiev school viewed the nature of mental 
reality does not match any of those proposed seven answers, though it is traditionally associated with the first proposed position stating that "the mental reality objectively exists and our knowledge of it should match the objective truth (theory of reflection)..." (Editorial, 2010, p. 74). However, the way that the members of A. Leontiev school viewed the nature of mental reality is far more complicated.

Firstly, they understand the "objectiveness" in a way close to that of non-classical or even post non-classical rationality and the criteria of the above rationality are those identified by V. Stepin (ref. e.g. Stepin, 2008) and not by those psychologists offering a quite peculiar interpretation of post non-classical rationality without including, for example, the objectivity principle in the list of the criteria (ref., e.g. M. Guseltseva, 2007).

Secondly, the "theory of reflection" (if we follow the mainstream and understand this way the vulgarized "Lenin's theory of reflection"), strictly speaking, does not form a part of basics of the theory of activity created by the members of A. Leontiev school. Moreover, A. Leontiev was reproached for constructivism.

However, the most essential is that the psychological theory of activity was based on the antidichotomic - dialectical - logic which is inseparably linked to monism (in the ontological sense as stated above). From the very moment he started to work out the theory of activity (see the report made in spring of 1934), A. Leontiev stated that the position of his school is opposed to dualism: "One of the greatest and the most terrible errors in psychology is the Cartesian error overemphasizing the actual historical opposition of inner, spiritual processes to the external material processes of life. The above opposition was generated by social division of labor. Consequently, the mind was greatly mystified. Our task is to destroy this mystification in psychology" (Leontiev, 1994, p. 44). In this relation he develops the ideas of L. Vygotsky who was preoccupied by the fact that "the logical structure of Cartesian doctrine on soul passions involving the spiritualist principle balanced by the mechanical one is being reconstructed in slightest detail under new historical circumstances" (Vygotsky, 1984, p. 314).

For A. Leontiev, the dualism of the Cartesian scheme is basically manifested by the postulate of immediacy. A whole monograph can be written about its appearance in psychology and the attempts to overcome it. So, we are going to say just a few words on this. It is known that for the so called classical psychology of consciousness (which was based 
on the system of ideas postulated by Cartesius and Locke) it is typical to use the dichotomy of the "external" (things and processes pertaining to the external world) and the "internal" (phenomena and processes of mind). The external and the internal had nothing in common (since, according to Cartesius, they were the forms of existence and manifestation of two fundamentally different substances), however they were linked in an odd mechanic way. This meant that once the receptor apparatus of the subject was stimulated, there came an immediate "response" to this stimulus in the form of subjective phenomena. The postulate of immediacy was also typical for behaviorism despite the fact that the subject-matter of psychology within the frames of this doctrine was considerably changed.

Thus, the unified universe of the human kind was divided into two abstract "halves". One of these was the self-contained ("observed from inside") universe of subjective phenomena. The other one was the universe of objective phenomena of behavior and physiological processes deprived of soul and "observed from outside". A. Asmolov believes that the paradoxes and oppositions in psychology are entailed by this division of the single field of the human nature into two opposite poles, the "subjectivism" and the "objectivism" (ref. A. Asmolov, 2007, p. 69). Thus, for example, the "cognitive" and "behavioristic" forms of a "particular human existence", the ideographical and nomothetic approaches, the biological and the social, the individual and the communal etc. in the man's psychology are studied abstractly and even sometimes opposed. It is natural that when the whole is so abstractly divided into two fundamentally different "halves" one may either limit oneself by studying just one of these "halves" (the "or - or" logic) or unite the opposite things applying the "and - and" principle.

I absolutely share A. Asmolov's thoughts when he compares the idea with Ptolemy's system in cosmogony and talks about "the Copernican overturn" made by the cultural and activity psychology. As a result, the binary analysis scheme typical for the "Ptolemy system" was replaced by another one and there the postulate of immediacy involving dichotomy of the subjective and the objective was eliminated by the newly introduced notion of activity.

I am referring to V. Allakhverdov's saying what the state of the contemporary physics would be if the Ptolemy's system that matched the "common sense" had prevailed over the Copernican theory, which 
seemed to be imperfect and absurd. To my mind, the time has come to make a choice in favor of the "Copernican" understanding of man's psychology that was introduced by the adherents of A. Leontiev school as well as in favor of their quite "absurd" view of the mind as a function of the indivisible subject-object reality, i.e. the function of activity. The most precise definitions of the essence of the mind as a special function of activity are given by A. Leontiev in his work Activity, Conscious, and Personality. In this book he also defined the subject-matter of psychology: "Activity forms a part of the subject-matter of psychology, but not as a "part" or an "element", but as its special function. The function is to position a subject in the material reality and to transform it into a form of subjectivity" (Leontiev, 2005, p. 73). Or else: “The man's activity forms a substance of his consciousness" (Ibid., p. 121). Obviously, this is quite an "absurd" interpretation of mind which does not match the vulgarized notion of mind as a "function of brain", "subjective image of the objective brain", "objectively right reflection" etc. Thus, the activity as subjectobject reality is the "substance" of the consciousness (and, I would say, the mind in general). That is why the mind and the consciousness should not be treated as the function of brain itself. As A. Leontiev said during a famous home discussion of 1969, we should not hammer in the mind "beneath the cranial roof" since this means nailed it in "a coffin". There is no escape from beneath the cranial roof. $\langle\ldots\rangle$. The consciousness $\langle\ldots\rangle$ is in the outside world as much as it is beneath the cranial roof. This is a spiritualized world and it is spiritualized by the man's activity" (Leontiev, 2005, p. 308).

Thus, the mind is a special function or even a "functional organ" (as A. Ukhtomsky defined it ${ }^{2}$ ) of activity identified by the special tasks it resolves, i.e. by the image (model) of the universe created by a subject basing on the different forms of orientation in it and by accordingly adjusting the activity of the subject in his own world. Consequently, the mind is initially positioned outside the reality that is defined, on the one hand, by the internal (whatever the meaning of this term is: brain, soul, selfcontained subjective) and, on the other hand, by the external (stimuli, environment etc.). Thus, the mental is neither objective nor subjective,

2 According to A. Ukhtomsky, a functional organ is a temporary combination of forces capable of achieving a certain goal. As far as psychology is concerned, this approach was widely used by $\mathrm{V}$. Zinchenko in many of his works. 
it is subject-objective reality available for scientific (and objective in the modern meaning of the word) research.

Due to the limited framework of this article, we are not able to look into the most essential consequences of such an antidichotomic position for resolving the fundamental problems of the modern psychology that are basically resolved now either with the use of "and - and" logic or the "or - or" logic. We would only refer to the previously published article (Sokolova, 2007) covering the elimination within the frames of the cultural and activity psychology the following dichotomies so essential for psychology: "internal vs. external", "reflection vs. construction", "natural science approach vs. humanitarian approach".

As far as the practical meaning of understanding the mind as a functional organ of activity is concerned, at the early stage of A. Leontiev school (during the 1930s and 1940s) a number of researches were conducted and it was proved that the specific characteristics of mental processes depend on the features of activity performed by the subject. Thus, for example, P. Zinchenko (1939) proved that the information becomes involuntary and is remembered if it is directly connected with the purpose of the activity but not with its conditions. In the mid-1930s A. Leontiev and A. Rosenblum conducted some researches of activities and interests of people coming to the Gorky Park in Moscow. As a result, it was demonstratively proven that "it is in the course of activity itself that the interest is activated entailing questions and the need for clarifications and help." (Leontiev \& Rosenblum, 1999, p. 422). This is why if we need, for example, to make children interested in obtaining scientific knowledge, we should involve them into specific activities that require scientific knowledge. At the same time K. Khomenko and O. Kontsevaya were studying the way a child understands metaphors. And it was demonstrated that children understand metaphors much better if they encounter these metaphors in a fairy tale but not if these metaphors are told to them by adults (ref. A. Zaporozhets, 1986). And during the 1940s some researches proved that the level of memorization among preschool age children do vary subject to the environment activities (Istomina, 1948) and that certain motives of activities play a role in regulating it (Manuilenko, 1948) etc. Even wounded soldiers showed different recovery rate subject to activities involving actions aimed at recovery (Zaporozhets \& Leontiev, 1945).

During the recent years similar ideas were expressed by our colleagues abroad. Thus, M. Cole in his book "Cultural-Historical Psychol- 
ogy: A Once and Future Discipline" (1997) gives some examples of studying different mental processes in the context of this or that "day-to-day activity". For instance, children say more complicated phrases and perform more complicated intellectual tasks in the course of spontaneous interaction than while being "interrogated by the adults" (ref. Cole, 1997, p. 265). A foreign language is also mastered more effectively if a child is involved in an activity that requires the knowledge of this language rather than when the child is left alone in a room with a working TV (ref. Ibid., p. 230). African children born and raised in a trading tribe would perform elementary arithmetic operations much better than children born and raised in a farming tribe (ref. Ibid., p. 238).

The above proves the general idea of cultural and activity psychology that any mental process is a function of a certain activity and that this process should not be isolated from the latter activity in the course of research.

\section{Conclusion}

Here is the general conclusion from the analysis we performed. The "Copernican" overturn made by the cultural and activity psychology interpreting mind as a functional organ of activity, i.e. as a subject-objective reality, was possible due to the purposeful application of dialectical logic. The latter involves a very complicated work on resolving the contradictions arising in psychology and "eliminating" dichotomies that arise inevitably if the reality is regarded in a non-dialectic way. A simple "summing" of different approaches applying the "and - and" principle and accepting "equivalency" thereof do not provide for a comprehensive picture of the reality studied by psychologists, of its functioning and development and, thus, do not provide for professional identification of psychologists preserving in psychology the existing pluralism and making it disintegrated, split into different fields, schools, and approaches. And what is the most essential is that this situation causes the general belief that psychology is a special field, that the laws of the other sciences are not applicable to it, that it is not possible to perform any systematic work therein, that progress there is rather doubtful etc. In this case the very existence of psychology as a science is questioned and this conclusion is opposed by the professionals who work in the field of the "highly

organized practice" dealing with the whole man. The life dialectics of 
this whole man should be represented in a complicated system of scientific notions that corresponds to this life and creating this system is an immense and highly important historical task as it was in L. Vygotsky's times. Efforts of several generations of psychologists are needed to resolve this task and, thus, the new psychology, as L. Vygotsky put it, "will be as much different from the today's one as, in Spinoza's words, Canis Major (the dog constellation) is different from a real dog" (Vygotsky, 1982, p. 436).

\section{References}

Allakhverdov, V. (2009). Razmyshlenie o nauke psikhologii s vosklitsatel'nym znakom [Reflection on the Science of Psychology with an Exclamation Mark]. St.-Petersburg.

Allakhverdov, V. (2010). Gde my? Otkuda my? Kuda my idyom? [Where Are We? Where Are We from? Where Are We Going to?] Psikhologiya. Zhurnal Vysshej shkoly ekonomiki, 7(1), 76-89.

Asmolov, A. (2007). Psikhologiya lichnosti. Kulturno-istoricheskoe ponimanie razvitiya cheloveka [Psychology of Personality. Cultural and Historical Understanding of Human Development]. Moscow.

Cole, M. (1997). Cultural-Historical Psychology: A Once and Future Discipline. Moscow.

Filosofiya: Entsiklopedichesky slovar' [Philosophy: Encyclopedic Dictionary]. (2004). Ed. by A. Ivin. Moscow.

Guseltseva, M. (2007). Kulturnaya psikhologiya: metodologiya, istoriya, perspektivy [Cultural Psychology: Methodology, History, Prospects]. Moscow.

Ilyenkov, E. (1999). O roli protivorechiya v poznanii [On Contradiction Role in the Process of Perception]. In E.V. Ilyenkov. Lichnost' $i$ tvorchestvo [Personality and Creation] (pp. 245-257). Ed. by I. Farman. Moscow.

Istomina, Z. (1948). Razvitie proizvol'noj pamyati v doshkol'nom vozraste [Development of Arbitrary Memory of the Preschool Age Children]. In Izvestiya APN RSFSR. Vyp. 14: Voprosy detskoj psikhologii. Doshkolny vozrast. (Trudy instituta psikhologii) [Proceedings of the Russian Academy of Pedagogical Science, issue 14: Issues of Child Psychology. Preschool Age. (Proceedings of the Institute of Psychology)] (pp. 51-88). Moscow; Leningrad.

Kornilova T., \& Smirnov S. (2006). Metodologicheskie osnovy psikhologii [Methodological Fundamentals of Psychology]. St.-Petersburg.

Krichevets, A. (2005). Mnogoetazhnaya psikhologiya. Eskizny proekt [Multistorey Psychology. Draft]. Mir psikhologii, 3(43), 218-233. 
Leontiev, A. (1994). Filosofiya psikhologii [Philosophy of Psychology]. Moscow.

Leontiev, A. (2005). Deyatel'nost'. Soznanie. Lichnost' [Activity, Conscious, and Personality]. Moscow.

Leontiev, A., \& Rosenblum, A. (1999). Psikhologicheskoe issledovanie deyatel'nosti i interesov posetitelej Tsentral'nogo Parka kultury i otdykha imeni Gorkogo (Predvarigel'noe soobshchenie) [Psychological Research on Activities and Interests of the Gorky Park Visitors (Preliminary Report)]. In A. Voyskunsky, A. Zhdan, \& O. Tikhomirov (Eds.). Traditsii $i$ perspektivy deyatel'nostnogo podhoda v psikhologii: Shkola A.N. Leontieva [Traditions and Prospects of the Pragmatist Approach in Psychology: A. Leontiev School] (pp. 370-425). Moscow.

Manujlenko, Z. (1948). Razvitie proizvol'nogo povedeniya u detej doshkol'nogo vozrasta [Development of Voluntary Behavior of the Preschool Age Children]. In Izvestiya APN RSFSR. Vyp. 14: Voprosy detskoj psikhologii. Doshkol'ny vozrast. (Trudy instituta psikhologii) [Proceedings of the Russian Academy of Pedagogical Science, issue 14: Issues of Child Psychology. Preschool Age. (Proceedings of the Institute of Psychology)] (pp. 89-123). Moscow; Leningrad.

Naumenko, L. (1968). Monizm kak printsip dialekticheskoj logiki [Monism as Principle of Dialectical Logic]. Alma-Ata.

Ot redkollegii [Editorial]. (2010). Psikhologiya: Zhurnal Vysshej shkoly ekonomiki, 7(1), 74-75.

Petrenko, V. (2005). Teoriya otrazheniya, konstruktivizm, intuitivism kak metodologicheskie paradigmy psikhologii [Theory of Reflection, Constructivism, Intuitionalism as Methodological Paradigms of Psychology]. In Trudy Yaroslavskogo metodologicheskogo seminara. T. 3: Metod psikhologii [Proceedings of Yaroslavl Methodological Seminar. Vol. 3: Method of Psychology] (pp. 291-308). Yaroslavl.

Sokolova, E. (2007). Metodologicheskoe edinstvo contra pluralizm: shkola A.N. Leontieva protiv sovremennoj dihotomizatsii psikhologii [Methodological Unity Contra Pluralism: A. Leontiev VS Modern Dichotomization of Psychology]. In A. Zhuravlev, \& A. Yurevich (Eds.). In Teoriya i metodologiya psikhologii. Postneklassicheskaya perspektiva [Theory and Methodology of Psychology. Post Non-Classical Prospects] (pp. 286-312). Moscow.

Stepin, V. (2008). Filosofiya nauki: Obshchie problemy [Philosophy of Science: General Problems]. Moscow.

Vygotsky, L. (1982). Istorichesky smysl psikhologicheskogo krizisa [Historical Sense of Psychological Crisis]. In L.S. Vygotsky, Collected works. Vol. 1 (pp. 291-436). Moscow: Prosveshenie.

Vygotsky, L. (1984). Uchenie ob emotsiyah: Istoriko-psikhologicheskoe issledovanie [Teaching on Emotions: Historical and Psychological Research]. In L.S. Vygotsky, Collected works. Vol. 6 (pp. 91-318). Moscow: Prosveshenie. 
Vygotsky, L. (2006). Dva fragmenta iz zapisnyh knizhek. Psikhofizicheskaya problema [Two Fragments of a Memo Book. Psychophysical Problem]. Vestnik RGGU. Psikhologiya [RSUH Gerald. Psychology], 1, 294-298.

Yurevich, A. (2003). "Metogologichesky liberalism” i paradigmal'ny status psikhologii ["Methodological Liberalism" and Paradigmal Status of Psychology]. In Trudy Yaroslavskogo metodologicheskogo seminara. T. 1: Metodologiya psikhologii [Proceedings of Yaroslavl Methodological Seminar. Vol. 1: Methodology of Psychology] (pp. 349-357). Yaroslavl.

Yurevich, A. (2005). Interpretativnye traditsii i parametry razvitiya psikhologicheskoj nauki [Interpretational Traditions and Parameters of Development of Psychological Science]. Voprosy psikhologii, 5, 119-130.

Yurevich, A. (2007). Integratsiya psikhologii: utopia ili real'nost'? [Integration of Psychology: Utopia or Reality?]. In A. Zhuravlev, \& A. Yurevich (Eds.), Teoriya i metodologiya psikhologii. Postneklassicheskaya perspektiva [Theory and Methodology of Psychology. Post Non-Classical Prospects] (pp. 503-523). Moscow.

Zaporozhets, A., \& Leontiev A. (1945). Vosstanovlenie dvizheniya: Issledovanie vosstanovleniya funktsij ruki posle raneniya [Recovery of Movement Ability: Research on a Wounded Hand Functions Recovery]. Moscow.

Zaporozhets, A. (1986). Osobennosti i razvtitie protsessa vospriyatiya [Features and Development of the Perception Process]. In A.V. Zaporozhets. Izbrannye psikhologicheskie trudy: $v 2$ tt. T. 1: Psikhicheskoe razvitie rebyonka [Selected Psychological Works: in 2 volumes. Vol. 1: Mental Development of a Child] (pp. 52-65). Moscow.

Zinchenko, P. (1939). Problema neproizvol'nogo zapominaniya [Problem of Involuntary Remembering]. In Nauchnye zapiski Kharkovskogo Gosudarstvennogo pedagogicheskogo instituta inostrannyh yazykov. T. I [Proceedings of the Kharkov State Pedagogical Institute of Foreign Languages. Vol. I] (pp. 145-187). Kharkov. 